$\mathrm{JOCM}$

34,2

Received 17 August 2020

Revised 26 November 2020 Accepted 22 December 2020

\title{
New organizational changes with blockchain: a focus on the supply chain
}

\author{
Vincenzo Varriale, Antonello Cammarano, Francesca Michelino and \\ Mauro Caputo \\ Department of Industrial Engineering, University of Salerno, Fisciano, Italy
}

\begin{abstract}
Purpose - The paper aims to present a systematic literature review (SLR) showing the benefits, challenges and future research of blockchain technology (BT) for the supply chain (SC), also suggesting how the features of BT can change the organizational aspects of the SC.

Design/methodology/approach - An SLR has been conducted to detect papers that contained the word "Blockchain" in their titles, keywords or abstracts. Consequently, a second filter to analyze BT papers for the $\mathrm{SC}$ was applied.

Findings - This paper shows through 31 variables classified into positive, negative and future directions of technology for the SC. For instance, BT will reduce time consuming of operations management and payments using smart contracts. In addition, integrating BT with other technologies will allow product tracking and sustainable production management.

Research limitations/implications - The selection of papers is limited to Scopus database and specifically to the Management Journal.

Practical implications - BT creates collaborative peer-to-peer and business-to-business markets. The technology automates several tasks such as order management, payment for goods, waste reduction and process control. Therefore, its use within the SCs will improve the productivity and profits of the participants. Originality/value - This paper is focused on BT for the SC area with 60 articles analyzed. In addition, 13 variables on benefits, eight variables on challenges and 12 points on future research directions were analyzed. This work will help researchers and entrepreneurs to deepen about the changes that BT offers in SC.
\end{abstract}

Keywords Blockchain, Supply chain, Systematic literature review, Benefits, Challenges, Future research Paper type Research paper

\section{Introduction}

Blockchain and cryptocurrencies have long been the focus of attention from the academics and entrepreneurs. Starting from the issues of security and privacy, the past few years have been crucial for the blockchain industry. The blockchain notion appears for the first time as a supporting technology in the field of virtual money (Nakamoto, 2008). Therefore, several definitions have been developed to clarify blockchain technology (BT) in its peculiarities (Fosso Wamba et al., 2020). Indeed, the first blockchain platform was Bitcoin created by Nakamoto in 2008. In particular, Bitcoin is a distributed ledger in which users can record virtual currency transactions, called cryptocurrencies (Swan, 2015). The difference between blockchain and other distributed ledgers is that BT records new transactions, thanks to the participants of the network who collect and insert them into the blocks for validation, without third parties (Christidis and Devetsikiotis, 2016). Therefore, these blocks are connected

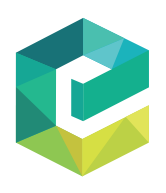

Journal of Organizational Change Management Vol. 34 No. 2, 2021 pp. $420-438$ Emerald Publishing Limited $0953-4814$

DOI 10.1108/JOCM-08-2020-0249
(C) Vincenzo Varriale, Antonello Cammarano, Francesca Michelino and Mauro Caputo. Published by Emerald Publishing Limited. This article is published under the Creative Commons Attribution (CCBY 4.0) licence. Anyone may reproduce, distribute, translate and create derivative works of this article (for both commercial and non-commercial purposes), subject to full attribution to the original publication and authors. The full terms of this licence may be seen at http://creativecommons.org/licences/by/4.0/legalcode

This paper forms part of a special section "Shades of change with and through Blockchain", guest edited by Luca Ferri, Rosanna Spanò and Yochanan Altman. 
together thanks to the hash functions that allow to trace the complete history of blocks by creating a chain of blocks, called blockchain (Kshetri, 2018).

Thanks to Bitcoin and cryptocurrencies, blockchain has had huge success in the financial field (Campbell-Verduyn, 2019; Csóka and Jean-Jacques Herings, 2018; Yu et al., 2018). Specifically, large interest was devoted to the use of cryptocurrency to decentralize financial transactions and payments to transfer money without transaction costs to the third parties (Holotiuk et al., 2019; Parkin, 2019; Vergne and Swain, 2016; Yin et al., 2019). Moreover, the initial coin offering (ICO), a way of financing start-ups projects through cryptocurrencies, is largely investigated (Barraza, 2019). In addition, BT may have significant impacts in the auditing and accounting sector in terms of governance, transparency and trust (Schmitz and Leoni, 2019).

Recently, blockchain studies have expanded into many areas, allowing to change the perspective of several activities (Miau and Yang, 2018). Indeed, BT has revolutionized organizational dynamics in manufacturing (Hughes et al., 2019; Mickiewicz and Rebmann, 2020). Specifically, within Industry 4.0, the technology has been integrated into management operations such as agile manufacturing (Gunasekaran et al., 2019) or used together with other technologies, e.g. additive manufacturing and robotics, to improve company's performance (Mandolla et al., 2019; Olsen and Tomlin, 2020).

Finally, the research is slowly moving towards the use of BT in the supply chain (SC). As the BT allows to insert transactions within the distributed ledger by using smart contracts, the order process would be highly optimized (Hasan et al., 2019; Martinez et al., 2019). In addition, BT can be used for cross-border shipments to overcome certification problems of food or luxury products and guarantee their origin and provenance (Choi, 2019; George et al., 2019; Spadoni et al., 2019). The application of BT would allow consumers and logistics partners to place greater trust to the entire SC (Montecchi et al., 2019; Queiroz et al., 2019). In literature, few works explored the use of this technology within SCs. There are many conceptual articles that explain the mechanism of the BT, but few evaluate its impacts within SCs (Manupati et al., 2020; Martinez et al., 2019). A series of indicators and parameters are lacking to make a real evaluation of the cost-benefits of this technology. One of the major criticalities within the business scenario is the lack of knowledge on how the technology works. Therefore, this work aims to show the benefits and advantages of BT for businesses, while for researchers, the challenges to be overcome and the possible future research developments are outlined.

The changes that BT promotes are radical for companies, both internally and externally, yet the development of the technology in $\mathrm{SC}$ is at an early stage. Hence, a systematic literature review (SLR) on the use of BT in SC has been addressed to understand how the technology impacts on the organizations. The study aims at having have a complete view of the current state of the art of BT in SC from the managerial side, evaluating the strengths and weaknesses of the technology in SC. In addition, future research areas are proposed for academics and managers who want to deepen their knowledge on this new technology. The paper proposes the analysis of 60 papers on the use of blockchain in the SC from 2008 to 2020 , evaluating possible managerial changes. In particular, the article provides different perspectives and identifies the main problems that should be solved to ensure its rapid adoption in companies including: privacy, security, technological performance and many others. Thanks to the benefits analysis, the work encourages managers to evaluate the use of $\mathrm{BT}$ in the SC to reduce costs, increase reputation and therefore increase profits. Finally, it lays the foundations for researchers to conduct the next future research on both the study of the technology in SCs and the assessment in terms of impacts, performance and sustainability.

In the following sections, a theoretical background of $\mathrm{BT}$ in $\mathrm{SC}$ is discussed, then the methodology and the results achieved are shown. In particular, the benefits and organizational changes, the problems to be overcome and the research scenarios using blockchain in SC are discussed. Finally, discussions and conclusions will close the work. 
JOCM 34,2

\section{Blockchain and supply chain}

One of the goals of SCs is to serve customers quickly and at the lowest costs (Flint, 2004). In recent times, scholars have focused on managing sustainable SCs by reducing carbon emissions (Saberi et al., 2019). In addition, one of the many risks in SCs is the opportunistic behaviour of SC actors, especially for global SCs (Cole et al., 2019). Therefore, the adoption of new technologies is necessary to deal with these issues. Indeed, one of the most promising non-financial areas of $\mathrm{BT}$ is related to the $\mathrm{SC}$, logistics and transportation area. In fact, the use of the BT would make transactions in the SC faster, reducing administrative and order delivery times (Kshetri, 2018).

Thanks to the possibility of sharing a distributed ledger among the actors of the network, the tracking data of several orders can be monitored along the shipments (Chang et al., 2020), enhancing trust among the partners. In addition, it is possible to reduce costs by eliminating intermediaries, given that each participant in the network can perform its own controls and, moreover, orders are managed by smart contract (Hasan et al., 2019). One of the areas that this technology is most affecting is the maritime shipping. Indeed, the naval sector chain is made up of many actors, such as organizations, customs, port authorities and certification authorities, so that the monitoring of global SCs is very complex (Bavassano et al., 2020). For instance, TradeLens shipping project aims to provide information to authorized participants in an SC only when necessary, allowing them to comply with regulatory frameworks while reducing administrative time and reducing risks through better monitoring (Jensen et al., 2019).

Also, the pharmaceutical SC could benefit from the use of blockchain, given several problems related to the transportation of medicines (Hastig and Sodhi, 2020; van Hoek, 2019). Indeed, many chemical compositions must be monitored from the point of view of temperature, humidity and exposure to light. Therefore, long time of shipments could change some parameters and damage the product. The use of blockchain integrated with technologies such as radio-frequency identification (RFID) sensors and the internet of things would allow complete product tracking. In fact, some projects have been launched in the pharmaceutical SC, such as MediLedger (Mattke et al., 2019).

Another area of significant change is the food SC: recently, the use of BT has been associated with agri-food, and several researches have been conducted in this area (Lezoche et al., 2020; Zhao et al., 2019). BT guarantees visibility and transparency to the network players; therefore, even if the actors do not trust each other, the guarantee of safety and reliability is managed by the technology, enhancing the final customer confidence in the end product (Schmidt and Wagner, 2019). Through authentication and certification, BT works as an anti-counterfeiting tool, protecting the origin and provenance of the product (Bai and Sarkis, 2020). Moreover, the use of BT is strictly connected to a sustainable improvement of the SC: indeed, knowing the quantity required by the market, it would allow to better manage global food production using a permanent and distributed ledger.

\section{Methodology}

An SLR is a consolidated method that provides a replicable and verifiable trace of procedures by reviewers (Tranfield et al., 2003). As BT was introduced for the first time in 2008, literature search covered the years 2008-2020. To standardize the research, the Scopus database was used, which has a rich collection of publications such as Emerald, IEEE, Springer, Elsevier, etc.

The applied methodology involves an iterative process, as shown in Figure 1:

(1) The search string TITLE-ABS-KEY (blockchain) was used within Scopus leading to 11,351 papers, with a complete overview of the use of technology in all areas.

(2) The second filter included only specific management journals that focus their attention on the operational side (Table A1), leading to 324 papers. 

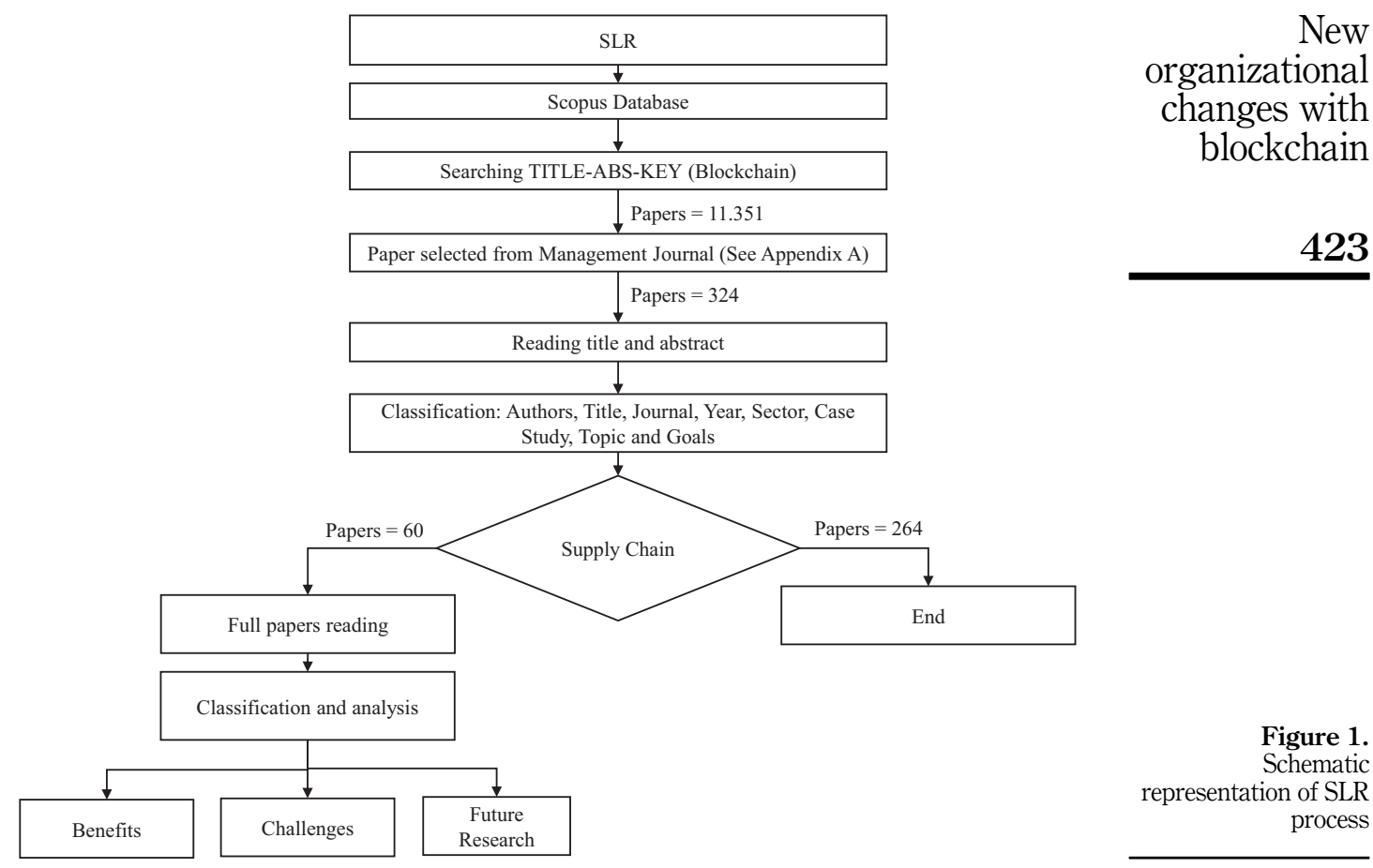

(3) Reading titles and abstracts of such papers, a classification was carried out into: authors, title, journal, year of publication, sector, case study, topic and objectives.

(4) A last filter was applied concerning BT within the SC, obtaining 60 papers for which the complete reading of the text was carried out.

(5) The analysis and classification of such paper was based on the benefits, challenges and future research hints of BT within the SC.

Table 1 shows how the complete reading of 60 articles for the period 2008-2020 is relevant for an SLR of BT in the SC field.

Table 2 shows the percentage frequency of the use of BT in the analyzed areas. In particular, the "new technologies" area refers to the use of new emerging technologies in different fields. Often, in several articles, the combined use of multiple technologies is

\begin{tabular}{|c|c|c|c|c|c|}
\hline Authors & $\begin{array}{l}\text { Research } \\
\text { method }\end{array}$ & Area & $\begin{array}{c}\text { Years } \\
\text { analyzed }\end{array}$ & $\begin{array}{l}\text { Selected } \\
\text { articles }\end{array}$ & \\
\hline Queiroz et al. (2019) & SLR & $\mathrm{SC}$ management and $\mathrm{BT}$ & 2008-2018 & 27 & \\
\hline Wang et al. (2019) & SLR & $\mathrm{SC}$ and $\mathrm{BT}$ & $2017-2018$ & 29 & \\
\hline $\begin{array}{l}\text { Bavassano et al. } \\
(2020)\end{array}$ & SLR & Logistics and BT & 2017-2019 & 37 & \\
\hline $\begin{array}{l}\text { Pournader et al. } \\
(2020)\end{array}$ & SLR & $\begin{array}{l}\text { SC, logistics, transportation and } \\
\text { BT }\end{array}$ & 2016-2018 & 48 & \\
\hline Kamble et al. (2020) & SLR & $\begin{array}{l}\text { Food SC with other emerging } \\
\text { technologies }\end{array}$ & 2000-2017 & 84 & $\begin{array}{r}\text { Comparison with other } \\
\text { SLRs of BT }\end{array}$ \\
\hline
\end{tabular}


JOCM
34,2

424

Table 2.

Composition of BT applications into several areas

\begin{tabular}{lrr}
\hline Area of application & $\#$ & $\%$ \\
\hline Business and industry & 38 & 12 \\
Energy sector & 29 & 9 \\
Financial & 75 & 23 \\
Health sector & 4 & 1 \\
Informatic sector & 47 & 15 \\
Innovation management & 7 & 2 \\
New technologies & 23 & 7 \\
Public sector & 12 & 4 \\
Social issues & 9 & 3 \\
Supply chain & 60 & 19 \\
Tourism & 4 & 1 \\
Others & 16 & 5 \\
\hline
\end{tabular}

reported, such as the internet of things with the blockchain or with artificial intelligence. Therefore, from the managerial side, the areas that have had the greatest successful are financial, IT and SC areas.

Figure 2 shows the number of articles published per year: the trend suggests increasing attention since 2017 in journals, with high impact factors (Table A1).

Table 3 shows the percentage frequency of papers based on the type of research method, with a preponderance of conceptual studies and technical implementations.

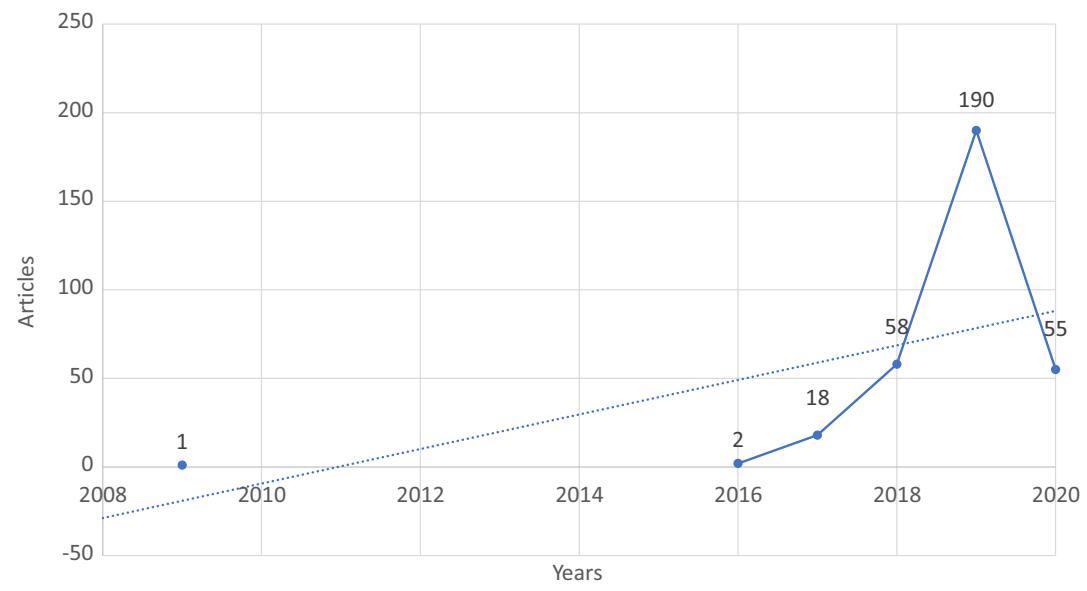

Figure 2.

Summary of papers published by year
Table 3.

Percentage composition of research methodologies

\begin{tabular}{llr}
\hline Research method & $\#$ & $\%$ \\
\hline Adoptions and limits & 44 & 14 \\
Case study & 18 & 6 \\
Conceptual studies & 85 & 26 \\
IT solutions & 20 & 6 \\
Literature review & 43 & 13 \\
Mathematical solutions & 20 & 6 \\
Statistical approach & 32 & 10 \\
Technical implementation & 52 & 16 \\
Editorial & 10 & 3
\end{tabular}




\section{Research results}

Benefits of blockchain technology for supply chain

BT is a decentralized certification authority that can offer economic and operational advantages to network companies (Longo et al., 2019). BT applications may concern the authentication and certification of goods (Choi, 2019) and can reduce the paperwork and the bureaucratic effort necessary for authentication during cross-border shipments (Bai and Sarkis, 2020).

Furthermore, the application of BT in SCM has huge benefits in terms of monitoring and automation of processes (Hasan et al., 2019). Indeed, BT can be programmed to automatically activate actions between nodes (such as payments or other events) once these events have been verified using smart contracts (Wang et al., 2019).

As blockchains are peer-to-peer networks, this can reduce the dependence on third parties (Wang et al., 2019). Moreover, decentralization and disintermediation help to connect several inputs from suppliers, producers, buyers, regulators who are far, have different rules or use different applications (Kamilaris et al., 2019).

In addition, BT improves the efficiency of the process, reducing operations number, average lead times and transport costs (Martinez et al., 2019; Manupati et al., 2020). In fact, blockchain has the power of digitally transforming maritime logistics systems, reducing costs and times at customs (Yang, 2019).

One of the important advantages of the blockchain is the immutability and integrity of transactions. The register is tamper-proof, and it is particularly useful for monitoring purposes (Pedersen et al., 2019). By agreeing unchanging transactions, BT can allow more market-oriented relationships within the SC (Schmidt and Wagner, 2019). BT is also a useful tool to overcome the problems of collaboration and trust, as it reduces the negative consequences of information asymmetry among the participants in an SC. Therefore, small and medium-sized enterprises can find ways to collaborate and share skills to survive in the market. Furthermore, BT discourages companies from any misconduct, such as fraud (Longo et al., 2019).

Blockchain guarantees reliability when implemented for food traceability (George et al., 2019) and can reduce potential losses from human error (Bai and Sarkis, 2020).

Thanks to BT in SC, it will be easy to get accurate demand forecasts. This helps SCs to mitigate the risks in which high inventory stocks are developed (Kamble et al., 2019). In addition, automatic payment upon verification of the conditions of a smart contract by a blockchain-based system increases inter-organizational trust (Min et al., 2019).

BT offers a way to improve security in logistics. Several algorithms and computational approaches are used to ensure that database logging is permanent, chronologically ordered and available to everyone else on the network (Wang et al., 2019). Indeed, BT can help the security of the generated data streams both from participants in the $\mathrm{SC}$ and from smart sensors, making the SC more reliable and safer (Queiroz et al., 2019; Pournader et al., 2020).

Traceability based on BT would allow to solve many SC problems (Lezoche et al., 2020; Yadav and Singh, 2020). In the food sector, blockchain-based data management can be useful for data relating to the use of resources, purchasing and other harmful agents (Kamble et al., 2020). Moreover, in the pharmaceutical sector, tracking and tracing the history of medicines sensitive to climatic changes can help improve procurement practices and ethical product management (Hastig and Sodhi, 2020).

Thanks to BT, transaction costs are reduced because third parties are not involved (Min, 2019). BT reduces behavioural uncertainty in player relationships, so it can reduce the costs associated with the transaction in an uncertain environment. The development of smart contracts will make possible to achieve a greater reduction in both costs and transaction times (Queiroz et al., 2019). organizational changes with blockchain 
JOCM 34,2

426
Furthermore, the data collected along the entire $\mathrm{SC}$ are recorded in $\mathrm{BT}$, and this increases transparency between the participants. Greater transparency implies easier identification of the processes that need to be improved, e.g. food safety problems (van Hoek, 2019). BT can trace the roots of the problem, and consequently, it can be detected the effect that has been generated. Hence, it is possible to plan a recovery and an improvement of the performance along the SC (Ivanov et al., 2019).

Finally, different intrinsic benefits of BT (Figure 3) come together to generate trust on the nature of technology (Chang et al., 2020; Montecchi et al., 2019). Table 4 summarizes the main benefits of blockchain also reporting the number of articles in which those research topics were addressed. Therefore, BT is a paradigm that will modify the operational and organizational processes of both public and private companies. Finally, BT will impact relational behaviours both internally and between organizations in the SC.

\section{Challenges of blockchain technology for supply chain}

One of the biggest challenges for BT is its degree of adoption in $\mathrm{SC}$ processes. BT requires new roles, responsibilities and skills to support different aspects of technology adoption. Technical skills and limited knowledge on the use of BT represent a barrier for its adoption (Saberi et al., 2019; van Hoek, 2020). In addition, SC partners want to see the benefits of implementation by competitors before using it (Hastig and Sodhi, 2020).

The introduction of BT requires investment in new hardware and software, which is expensive for network partners. For this reason, industrial managers are sceptical about the high implementation costs and the potential impact of blockchain applications (Kamble et al., 2019; Saberi et al., 2019). On the other hand, big companies, which have more resources, could implement a blockchain-based system because the costs for them are not prohibitive.

As the Bitcoin blockchain has highlighted energy consumption problems, one of the challenges is to quantify the energy impacts on its use in SC management (Fosso Wamba et al., 2020).

Although the BT has been perceived as an innovation that gains benefits from being implemented in connection with all actors in the SC, the effects of BT on the medium and small businesses is unclear (Bavassano et al., 2020). As BT implementation requires the agreement and willingness of partners, some organizations may be reluctant to share valuable and critical information because other companies may exploit this information as a competitive advantage (Montecchi et al., 2019; Saberi et al., 2019).

Another problem is the regulation that does not allow the adoption of the BT. Indeed, often the regulation prohibits the use of digital certificates but prefers signatures and paper materials, especially in maritime transport (Jensen et al., 2019). However, the introduction of
Figure 3.

Trust is generated by the combination of BT features

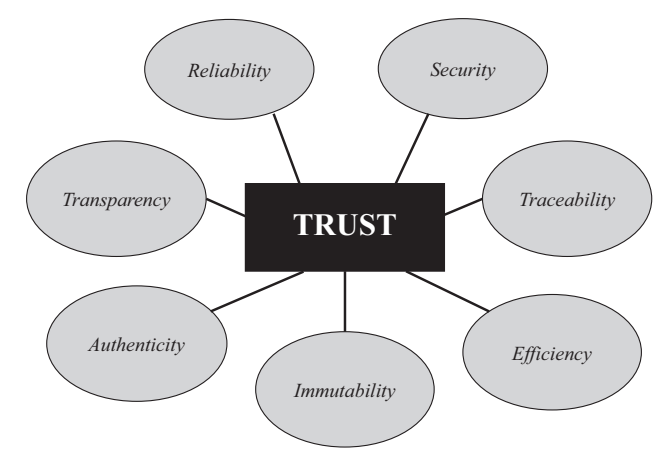




\begin{tabular}{|c|c|c|c|c|}
\hline Benefits & Authors & Description & $\begin{array}{l}\text { No. } \\
\text { articles }\end{array}$ & \\
\hline $\begin{array}{l}\text { Authentication and } \\
\text { certification }\end{array}$ & $\begin{array}{l}\text { Bai and Sarkis (2020), Choi } \\
\text { (2019), Longo et al. (2019) }\end{array}$ & $\begin{array}{l}\text { The capability to confirm the quality } \\
\text { of an asset using digital signatures } \\
\text { followed by a registration on a } \\
\text { distributed register }\end{array}$ & 9 & blockchain \\
\hline Automation & $\begin{array}{l}\text { Hasan et al. (2019), Wang } \\
\text { et al. (2019) }\end{array}$ & $\begin{array}{l}\text { The capability to manage } \\
\text { automatically actions after specific } \\
\text { events }\end{array}$ & 6 & 427 \\
\hline $\begin{array}{l}\text { Disintermediation and } \\
\text { decentralization }\end{array}$ & $\begin{array}{l}\text { Kamilaris et al. (2019), Wang } \\
\text { et al. (2019) }\end{array}$ & $\begin{array}{l}\text { Managing transactions without } \\
\text { intermediaries, i.e. without the } \\
\text { presence of trusted central authorities. } \\
\text { In addition, information is distributed } \\
\text { between several nodes to ensure } \\
\text { cybersecurity }\end{array}$ & 9 & \\
\hline Efficiency & $\begin{array}{l}\text { Manupati et al. (2020), } \\
\text { Martinez et al. (2019), } \\
\text { Yang (2019) }\end{array}$ & $\begin{array}{l}\text { Focused monitoring, high speed on } \\
\text { the operations number and reduced } \\
\text { time consuming on process } \\
\text { management }\end{array}$ & 33 & \\
\hline Immutability & $\begin{array}{l}\text { Pedersen et al. (2019), Schmidt } \\
\text { and Wagner (2019) }\end{array}$ & $\begin{array}{l}\text { Data cannot be changed or tampered } \\
\text { without network consensus }\end{array}$ & 10 & \\
\hline Partner support & Longo et al. (2019) & $\begin{array}{l}\text { The technology improves greater } \\
\text { collaboration between participants in } \\
\text { the SC }\end{array}$ & 8 & \\
\hline Reliability & $\begin{array}{l}\text { Bai and Sarkis (2020), George } \\
\text { et al. (2019) }\end{array}$ & $\begin{array}{l}\text { It supports the collection, storage and } \\
\text { management of data, managing } \\
\text { crucial information about products } \\
\text { and the participants of SC }\end{array}$ & 11 & \\
\hline Risks reduction & $\begin{array}{l}\text { Kamble et al. (2020), Min } \\
\text { et al. (2019) }\end{array}$ & $\begin{array}{l}\text { Reducing financial and fraud risks } \\
\text { between the actors involved }\end{array}$ & 25 & \\
\hline Security & $\begin{array}{l}\text { Pournader et al. (2020), } \\
\text { Queiroz et al. (2019), Wang } \\
\text { et al. (2019) }\end{array}$ & $\begin{array}{l}\text { The distributed and encrypted nature } \\
\text { of BT makes it difficult to tamper with } \\
\text { the technology }\end{array}$ & 22 & \\
\hline $\begin{array}{l}\text { Traceability (tracking } \\
\text { and tracing) }\end{array}$ & $\begin{array}{l}\text { Hastig and Sodhi (2020), } \\
\text { Kamble et al. (2019), Lezoche } \\
\text { et al. (2020), Yadav and Singh } \\
(2020)\end{array}$ & $\begin{array}{l}\text { Each transaction on the distributed } \\
\text { ledger can be traced and tracked back } \\
\text { to its origin and provenance }\end{array}$ & 25 & \\
\hline Transaction cost & $\begin{array}{l}\text { Min (2019), Queiroz et al. } \\
\text { (2019), Schmidt and Wagner } \\
\text { (2019) }\end{array}$ & $\begin{array}{l}\text { Reducing transaction costs related to } \\
\text { relationships with network partners }\end{array}$ & 16 & \\
\hline $\begin{array}{l}\text { Transparency } \\
\text { (visibility) }\end{array}$ & $\begin{array}{l}\text { van Hoek (2019), Ivanov } \\
\text { et al. (2019) }\end{array}$ & $\begin{array}{l}\text { The distributed ledger is transparent } \\
\text { and visible to the participants and it is } \\
\text { easy to monitor and verify }\end{array}$ & 25 & \\
\hline Trust & $\begin{array}{l}\text { Chang et al. (2020), Montecchi } \\
\text { et al. (2019) }\end{array}$ & $\begin{array}{l}\text { The transactions are immutable; in } \\
\text { this way, everyone can view them, } \\
\text { which increases trust in the product } \\
\text { and on the actors involved }\end{array}$ & 21 & $\begin{array}{r}\text { Table } 4 . \\
\text { Benefits of BT for SC }\end{array}$ \\
\hline
\end{tabular}

precise regulation is still a long way off because it requires that each local authority and government first use digital platforms within their systems (Kittipanya-Ngam and Tan, 2020). Finally, as there is no single owner of a blockchain system, legal and regulatory frameworks should clarify the responsibility for partner actions (Chang et al., 2020).

Furthermore, public blockchain has privacy issues. Indeed, privacy in an open network, such as cross-border shipments, is a crucial challenge (Chang et al., 2020). As each transaction 
JOCM 34,2

428

is recorded on a distributed ledger, all users can be identified with their public keys. Although this ensures transparency and trust, it does not protect user privacy. This privacy is very important in the food SC because many participants compete. Therefore, keeping a high level of privacy is one of the main challenges (Kamilaris et al., 2019; Zhao et al., 2019). However, as $\mathrm{BT}$ is visible to anyone on the network, there may be prevention of the cyber-attacks to steal the information by evaluating the number of transitions that a specific participant recorded on the network. Therefore, from this volume of transactions, it is possible to understand the sales volumes and the strategies that each actor carries out within the SC. Given the large number of nodes to manage in the SCs, privacy management is complex.

A further issue of inefficiency is the lack of a standard information platform (Saberi et al., 2019), which implies a lack of integration between participants in the SC and generates disagreements on the interpretation of documents (Jensen et al., 2019). In addition, companies have already spent on enterprise resource planning (ERP), customer relationship management (CRM) or other information technology (IT) systems. The blockchain-based solution should integrate with these existing systems at different levels (Hastig and Sodhi, 2020).

Finally, technological performance is divided into various problems such as storage capacity, scalability, throughput and latency issue (Zhao et al., 2019). Indeed, BT has limitations related to the speed of transactions recording that decreases with the increasing of the nodes (Hastig and Sodhi, 2020; Helo and Hao, 2019). In addition, BT has limitations as to the volume of transactions and the time required to add data to the blockchain volume. However, in supply and transport chains, the volume of transactions is high; therefore, the incapacity of blockchain to meet such high volumes is worrying (Pournader et al., 2020). Figure 4 shows how the technological barriers are the main challenges of BT adoption within the SC. This is also highlighted by the high number of articles that address such problems.

Table 5 summarizes the main challenges of blockchain with the number of related papers.

\section{Future research of blockchain technology for supply chain}

Many authors outlined future horizons for research in the field of BT for the SC. Regarding the adoption of $\mathrm{BT}$ in the $\mathrm{SC}$, one of the possibilities is the evaluation of the number of actors involved (Yoon et al., 2020). Furthermore, if the challenge of increasing the number of nodes within the platform is overcome, a BT application in the automotive and technology industry

Figure 4.

The main challenge of BT for SC is technological barriers

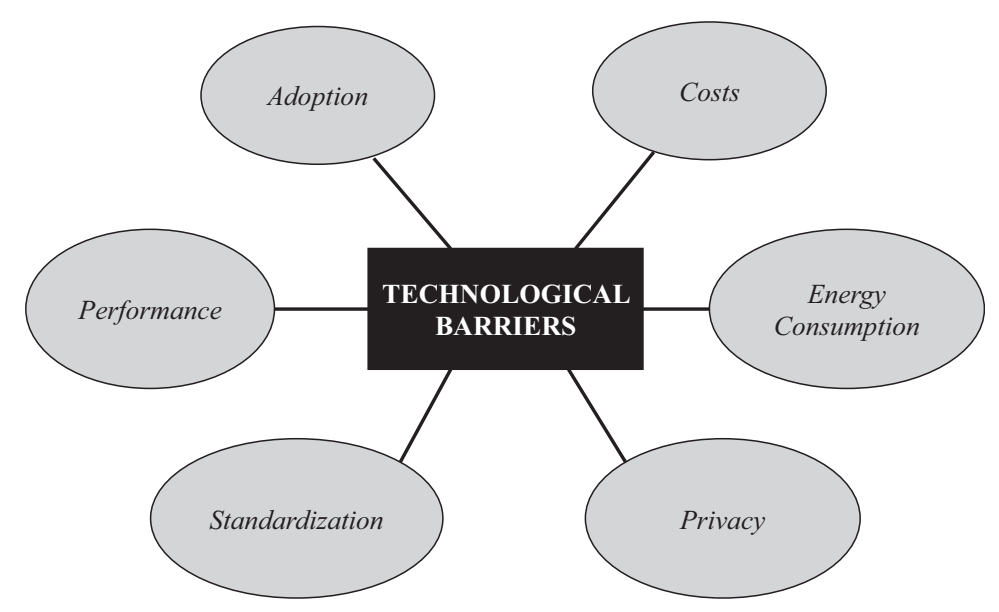




\begin{tabular}{|c|c|c|c|c|}
\hline Challenges & Authors & Description & $\begin{array}{c}\text { No. } \\
\text { articles }\end{array}$ & $\begin{array}{r}\text { New } \\
\text { organizational }\end{array}$ \\
\hline Adoption & $\begin{array}{l}\text { Hastig and Sodhi (2020), Saberi } \\
\text { et al. (2019), van Hoek (2020) }\end{array}$ & $\begin{array}{l}\text { The adoption requires specific technical } \\
\text { managerial knowledge and skills }\end{array}$ & 17 & blockchain \\
\hline $\begin{array}{l}\text { Implementation } \\
\text { cost }\end{array}$ & $\begin{array}{l}\text { Kamble et al. (2019), Saberi et al. } \\
\text { (2019), Zhang et al. (2020) }\end{array}$ & $\begin{array}{l}\text { High implementation costs are related to } \\
\text { the hardware and software } \\
\text { infrastructure present among all the SC } \\
\text { partners }\end{array}$ & 10 & 429 \\
\hline $\begin{array}{l}\text { Energy } \\
\text { consumption }\end{array}$ & Fosso Wamba et al. (2020) & $\begin{array}{l}\text { High energy consumption in public } \\
\text { blockchain }\end{array}$ & 1 & \\
\hline Organization & $\begin{array}{l}\text { Bavassano et al. (2020), } \\
\text { Montecchi et al. (2019), Saberi } \\
\text { et al. (2019) }\end{array}$ & $\begin{array}{l}\text { Process issues between small and } \\
\text { medium-sized enterprises of the network }\end{array}$ & 15 & \\
\hline $\begin{array}{l}\text { Regulation and } \\
\text { governance }\end{array}$ & $\begin{array}{l}\text { Chang et al. (2020), Jensen et al. } \\
\text { (2019), Kittipanya-Ngam and } \\
\text { Tan (2020) }\end{array}$ & $\begin{array}{l}\text { A regulatory framework regarding } \\
\text { blockchain transactions does not exist }\end{array}$ & 11 & \\
\hline Privacy & $\begin{array}{l}\text { Chang et al. (2020), Kamilaris } \\
\text { et al. (2019), Zhao et al. (2019) }\end{array}$ & $\begin{array}{l}\text { Sharing information between partners } \\
\text { can lead to opportunistic behaviour }\end{array}$ & 16 & \\
\hline Standardization & $\begin{array}{l}\text { Hastig and Sodhi (2020), Jensen } \\
\text { et al. (2019), Saberi et al. (2019) }\end{array}$ & $\begin{array}{l}\text { The absence of a standard generates } \\
\text { communication problems between the } \\
\text { participants of the network }\end{array}$ & 9 & \\
\hline $\begin{array}{l}\text { Technology } \\
\text { performance }\end{array}$ & $\begin{array}{l}\text { Hastig and Sodhi (2020), Helo } \\
\text { and Hao (2019), Pournader et al. } \\
\text { (2020), Zhao et al. (2019) }\end{array}$ & $\begin{array}{l}\text { BT has technical problems such as } \\
\text { storage capacity, scalability, throughput } \\
\text { and latency issue. These problems are } \\
\text { related to the slow speed of storage data, } \\
\text { reading transactions and data } \\
\text { management }\end{array}$ & 41 & $\begin{array}{r}\text { Table 5. } \\
\text { Challenges of BT } \\
\text { for SC }\end{array}$ \\
\hline
\end{tabular}

SC can be developed (Kshetri, 2018). Furthermore, why BT should be preferred rather than using traditional technologies already used in companies, such as electronic data interchange (EDI) systems, it can be further studied (Schmidt and Wagner, 2019).

Another promising research possibility could include evaluating the combined effects on the SC by integrating BT with other emerging technologies such as cloud computing, robotics, artificial intelligence and internet of things (Hartley and Sawaya, 2019; Zhang et al., 2020).

As BT works in environments without intermediaries, one issue is how security technology can help increase trust in partners and how the buyer-supplier dynamics can change when technology creates trust between them (Manupati et al., 2020; Pournader et al., 2020).

Furthermore, research should explore how the introduction of the blockchain can modify obsolete intermediation business models and which new intermediation services could raise (Schmidt and Wagner, 2019). In addition, the use of open innovation concepts within business models using BT shows an important research gap in the SC literature (Rahmanzadeh et al., 2020).

In recent years, research has been pushing for the analysis of real cases studies of BT applications within the SC (Cole et al., 2019). Future research should explore whether SCs will need banks to regulate financial transactions or whether distributors will continue to add value to SCs (Wang et al., 2019).

Certainly, there is a need to research new BT frameworks in multiple SC scenarios. On the other hand, future studies can evaluate the effects of the blockchain-based traceability framework proposed from different perspectives, such as the calculation of costs, the speed of processing transactions, the storage capacity and the overall efficiency of the SCs 
JOCM 34,2

430

(Azzi et al., 2019; Dolgui et al., 2020; Zhao et al., 2019). In addition, a research gap is how much the economic advantage created by the operational efficiency in container shipping achieved, thanks to blockchain, will exceed its implementation costs (Tang and Veelentuf, 2019).

Furthermore, regulation and standardization can advance the development of the blockchain by providing common ways of working at an international level, seek how to develop interoperability between systems, how to guarantee trust in the market and, finally, indicate a guideline for greater innovation (Chang et al., 2020; Zhao et al., 2019).

It is important to understand in which situations buyers and suppliers are willing to share information. Hence, it would be appropriate to investigate what are the disadvantages of having a greater visibility of the SC (Kamble et al., 2020; Schmidt and Wagner, 2019).

Therefore, possible insights could investigate whether trust in technology can completely replace trust in personal relationships. Specifically, how these new decentralized organizational forms can guarantee trust and how they can be crucial (Choi, 2019; Queiroz et al., 2019; Schmidt and Wagner, 2019).

Researchers could also explore how cryptocurrency can influence cash flow and SC purchases. SC partners could settle their payments using cryptocurrency. In addition, how necessary is the simultaneous presence of purchasing managers with smart contracts (Kurpjuweit et al., 2019; Wang et al., 2019) and whether the development of smart contracts can effectively facilitate financial and production data and transactions between participants (Choi et al., 2019).

Finally, the issue of sustainability in SC management (SCM) is much discussed. Indeed, research gaps concern how blockchain can be used to manage SCs in a sustainable way. On the other hand, very few works have shown how blockchain facilitates the reduction of carbon dioxide (CO2) emissions (Kamble et al., 2020; Schmidt and Wagner, 2019; Zhang et al., 2020). Future research can also go in the direction of the United Nations Sustainable Development Goals (Saberi et al., 2019).

The underlying theme of future research seems to be the application development in the $\mathrm{SC}$ processes and not only in the orders and payments management. Figure 5 highlights the need to propose new simulation applications to know the further potential of blockchain.

Table 6 summarizes the new perspectives of blockchain reporting the number of related papers.

Figure 5.

The role of future research is the development of new frameworks for the quantitative evaluation of SC processes

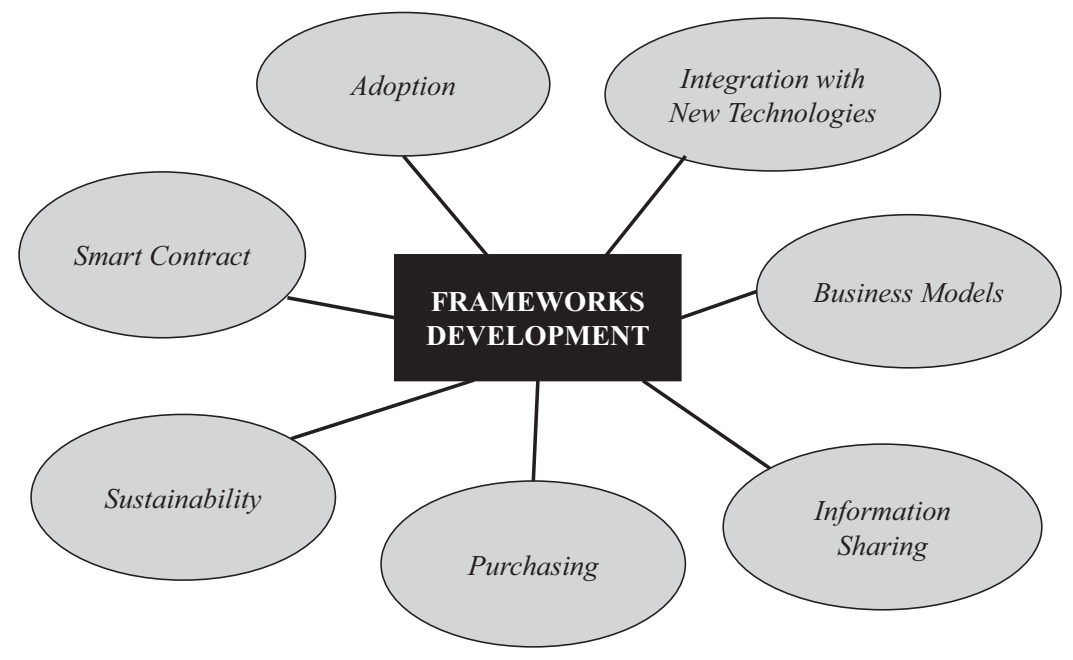




\begin{tabular}{|c|c|c|c|c|}
\hline Future research & Authors & Description & $\begin{array}{l}\text { No. } \\
\text { articles }\end{array}$ & $\begin{array}{r}\text { New } \\
\text { organizational }\end{array}$ \\
\hline Adoption & $\begin{array}{l}\text { Kshetri (2018), Schmidt and } \\
\text { Wagner (2019), Yoon et al. } \\
\text { (2020) }\end{array}$ & $\begin{array}{l}\text { Factors that slow down the adoption } \\
\text { of technology in the SC }\end{array}$ & 13 & blockchain \\
\hline $\begin{array}{l}\text { Blockchain } \\
\text { integration with new } \\
\text { technologies }\end{array}$ & $\begin{array}{l}\text { Hartley and Sawaya (2019), } \\
\text { Zhang et al. (2020) }\end{array}$ & $\begin{array}{l}\text { Studying on BT potential integrated } \\
\text { with other emerging technologies }\end{array}$ & 9 & 431 \\
\hline Blockchain security & $\begin{array}{l}\text { Manupati et al. (2020), } \\
\text { Pournader et al. (2020) }\end{array}$ & $\begin{array}{l}\text { Mitigation of security problems } \\
\text { among network participants }\end{array}$ & 3 & \\
\hline Business models & $\begin{array}{l}\text { Rahmanzadeh et al. (2020), } \\
\text { Schmidt and Wagner (2019) }\end{array}$ & $\begin{array}{l}\text { Reorganization of business models } \\
\text { using BT }\end{array}$ & 4 & \\
\hline Case studies & $\begin{array}{l}\text { Cole et al. (2019), Wang et al. } \\
\text { (2019) }\end{array}$ & $\begin{array}{l}\text { Real-world case study and } \\
\text { performance evaluation }\end{array}$ & 7 & \\
\hline $\begin{array}{l}\text { Framework } \\
\text { development }\end{array}$ & $\begin{array}{l}\text { Azzi et al. (2019), Dolgui et al. } \\
\text { (2020), Tang and Veelenturf } \\
\text { (2019), Zhao et al. (2019) }\end{array}$ & $\begin{array}{l}\text { Developing new simulation models } \\
\text { for the optimization of SC operations }\end{array}$ & 12 & \\
\hline $\begin{array}{l}\text { Governance } \\
\text { disruptions }\end{array}$ & $\begin{array}{l}\text { Chang et al. (2020), Zhao et al. } \\
\text { (2019) }\end{array}$ & $\begin{array}{l}\text { Reach consensus on regulations and } \\
\text { standardizations }\end{array}$ & 10 & \\
\hline Information sharing & $\begin{array}{l}\text { Kamble et al. (2020), Schmidt } \\
\text { and Wagner (2019) }\end{array}$ & $\begin{array}{l}\text { Investigating what are the } \\
\text { information to share in the } \\
\text { distributed ledger and how } \\
\text { relationships between partners can } \\
\text { change }\end{array}$ & 6 & \\
\hline Organizational forms & $\begin{array}{l}\text { Choi (2019), Queiroz et al. (2019), } \\
\text { Schmidt and Wagner (2019) }\end{array}$ & $\begin{array}{l}\text { Detecting how decentralized } \\
\text { organizations can guarantee trust }\end{array}$ & 7 & \\
\hline Purchasing & $\begin{array}{l}\text { Kurpjuweit et al. (2019), Wang } \\
\text { et al. (2019) }\end{array}$ & $\begin{array}{l}\text { How the scenarios of purchases } \\
\text { within the SCs change, thanks to the } \\
\text { use of cryptocurrencies }\end{array}$ & 8 & \\
\hline Smart contract & Choi et al. (2019) & $\begin{array}{l}\text { Smart contract development to } \\
\text { automate financial and production } \\
\text { processes }\end{array}$ & 2 & \\
\hline Sustainability & $\begin{array}{l}\text { Kamble et al. (2020), Saberi et al. } \\
\text { (2019), Schmidt and Wagner } \\
\text { (2019), Zhang et al. (2020) }\end{array}$ & $\begin{array}{l}\text { Assessment of the environmental, } \\
\text { social and economic impacts of the } \\
\text { use of BT in the SC }\end{array}$ & 8 & $\begin{array}{r}\text { Table } 6 . \\
\text { Future research } \\
\text { agenda }\end{array}$ \\
\hline
\end{tabular}

\section{Discussions and conclusions}

The results of the SLR provide multiple insights. After the methodological point of view, it is highlighted that articles on blockchain topics are growing for managerial journals. Indeed, the number of articles in the managerial area reached 190 in 2019. In addition, the results show that, even if the journals are managerial, the topics covered concern different areas: financial, IT, industrial, health and SC. As the blockchain was born as a virtual currency platform, the amount of financial papers has a greater share. Nevertheless, the vision on blockchain is changing, thanks to its characteristics including decentralization and disintermediation. Indeed, the blockchain can be considered as a decentralized computer that publicly executes programs: the computer is not physical, but its operations consist of collaboration of several computers belonging to different organizations. However, the difference from other IT systems is that the data entered in blockchain are verifiable by everyone, making it a transparent and an anti-counterfeiting tool. Therefore, it is starting from the new role given to blockchain that the academic and industrial world has approached the use of this new technology. Of course, the path to new horizons is still long: more than $50 \%$ of the managerial articles concern theoretical aspects and states of the art, whereas only few articles focus on the implementation of some processes using blockchain. Hence, it is 
$\mathrm{JOCM}$ 34,2

necessary to deepen the adoption of blockchain through the study of real case studies or through simulation models. Indeed, only eight papers among the analyzed sample were technical implementation articles.

Consequently, the $\mathrm{SC}$ is a fertile ground for the application of technology. Using blockchain as an anti-counterfeiting tool is one of the many reasons that pushes companies to adopt this technology. The blockchain articles in the area of SC mainly concern the themes of reducing the risk of fraud, obtained through the complete traceability and visibility of the SC. In addition, they also focus on improving the efficiency of shipping and order management processes. The use of smart contracts will allow to change and facilitate the purchase and control processes of the products shipped. Day-to-day monitoring of product phases (i.e. product conditions or payment status) allows to place greater trust in the supply system.

On the other hand, the use of smart contracts, which are programs, could slow down the blockchain system. Therefore, technological performance decreases when the code implemented by these contracts increases. This is one of the biggest challenges in blockchain, slowing down its adoption. In addition, the implementation costs for all actors in the $\mathrm{SC}$ can be a huge problem for adoption, as it is necessary to consider not only big organizations but also small and medium-sized enterprises that may have difficulty to access these new technologies.

Finally, the paper offers interesting insights into future research. The new directions mainly concern developments and simulations of models that improve the efficiency of SC processes. In addition, BT works through bits and helps to improve processes when there is a digitization of the assets (e.g. cryptocurrencies). Therefore, BT must be integrated with other technologies to transform a physical asset into a digital one.

In conclusions, it is possible to summarize the benefits, challenges and future research in three key concepts, respectively: trust, technological barriers and new frameworks development. These three concepts are linked together, as trust is generated by the operating logic of the technology and BT technological barriers need to be broken down into the study of simulation models to achieve quantitative results.

Therefore, the main future directions converge in the development of virtual and real blockchain models for SC to understand their effective usefulness. In fact, the concept of trust will be further consolidated through the achievement of concrete analytical results that will highlight the strengths of the technology. In this way, academics and entrepreneurs can concretely observe how all the benefits mentioned above are combined to provide greater value to $\mathrm{SC}$ processes.

Hence, the development of new frameworks is crucial for achieving economic results and the introduction of new metrics for optimizing processes to reduce scepticism about this new technology. For this reason, it is essential to highlight these gaps by comparing results achieved with traditional parameters used in $\mathrm{SC}$ with those obtained through a blockchain system. In addition, it is necessary to include problems such as the implementation, management and maintenance costs of the technology and privacy issues within these simulation models.

The simulation models should not be limited to the optimization of order management and automated payment among the players in the SC, but they should investigate several areas such as warehouse management, information sharing among the actors and the optimization of production processes and resources from a sustainable point of view. This should be implemented using and creating new smart contracts to achieve the complete connection and automation required for Industry 4.0.

Figure 6 shows how trust, frameworks development and technological barriers are linked together

The practical implications of the use of blockchain in SCs are various by adopting BT; it is possible to create a peer-to-peer collaborative market, which will allow trading avoiding 


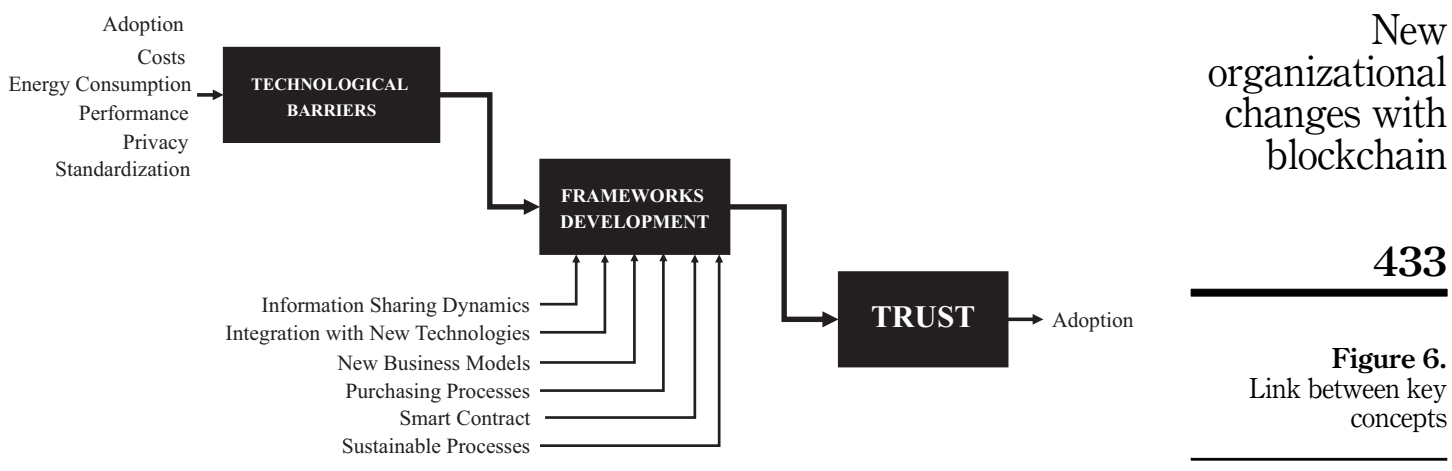

frauds or opportunistic behaviours. This will be possible, thanks to the intrinsic security features of the blockchain operation. All data are encrypted, and accesses are authenticated through the use of keys. Furthermore, the technology can automate several practices such as order fulfilment, distribution, payment of goods, communication of information. Thanks to the constant monitoring of each product, it will be possible to reduce the waste of resources, such as water and other raw materials. Therefore, the use of blockchain will improve productivity, reduce the time spent controlling processes and provide companies with additional profits.

Regarding the social implications, BT can help SCs detect suppliers who do not comply with regulations and standards. Furthermore, blockchain integrated with other technologies can improve occupational health and safety. For example, the technology can be used as a distributed ledger for collecting data such as: temperature, humidity, lighting, noise and ventilation. This data can be acquired and collected by sensors before it can be stored on the blockchain platform. Finally, this information can be used to help improve working conditions and business performance.

The proposed work provides a first starting point for the evaluation of SC using BT, showing positive, negative and uncertainty aspects of technology. In particular, the article provides an overview of the features that the adoption of BT in SC can perform. The analysis of benefits and challenges brings clarity to entrepreneurs on the exploitation of technology within the SCs in terms of costs, tracking, reliability, authentication and certification. It also sets the stage for researchers for new future research criteria. This 60-article SLR analyzed on $\mathrm{BT}$ in SCs is the most extensive in the management engineering industry. The main limitations relate to the absence of grey literature and the other non-managerial engineering journals were not considered. Finally, although the selection of search terms used in the study was as wide as possible by searching in the title, abstract and keywords only the term blockchain, this choice may have excluded some articles from this SC review. Furthermore, although strands of future research have been proposed, these are entirely theoretical in view of real future developments. Therefore, once BT has matured within the $\mathrm{SC}$, a new revision of the literature will be required.

\section{References}

Azzi, R., Chamoun, R.K. and Sokhn, M. (2019), "The power of a blockchain-based supply chain", Computers and Industrial Engineering, Vol. 135, pp. 582-592.

Bai, C. and Sarkis, J. (2020), "A supply chain transparency and sustainability technology appraisal model for blockchain technology", International Journal of Production Research, Vol. 58 No. 7 , pp. 2142-2162. 
JOCM 34,2

Barraza, B. (2019), "The worth of words: how technical white papers influence ICO blockchain funding", MIS Quarterly Executive, Vol. 18 No. 4, Article 8, pp. 281-286, available at: https:// aisel.aisnet.org/misqe/volle/iss4/8.

Bavassano, G., Ferrari, C. and Tei, A. (2020), "Blockchain: how shipping industry is dealing with the ultimate technological leap", Research in Transportation Business and Management, Vol. 34, 100428.

Campbell-Verduyn, M. (2019), "Introduction to special section on blockchains and financial globalization”, Global Networks, Vol. 19 No. 3, pp. 283-290.

Chang, Y., Iakovou, E. and Shi, W. (2020), "Blockchain in global supply chains and cross border trade: a critical synthesis of the state-of-the-art, challenges and opportunities", International Journal of Production Research, Vol. 58 No. 7, pp. 2082-2099.

Choi, T.M. (2019), "Blockchain-technology-supported platforms for diamond authentication and certification in luxury supply chains", Transportation Research Part E: Logistics and Transportation Review, Vol. 128, pp. 17-29.

Choi, T.M., Wen, X., Sun, X. and Chung, S.H. (2019), "The mean-variance approach for global supply chain risk analysis with air logistics in the blockchain technology era", Transportation Research Part E: Logistics and Transportation Review, Vol. 127, pp. 178-191.

Christidis, K. and Devetsikiotis, M. (2016), "Blockchains and smart contracts for the Internet of Things", IEEE Access, Vol. 4, pp. 2292-2303.

Cole, R., Stevenson, M. and Aitken, J. (2019), "Blockchain technology: implications for operations and supply chain management", Supply Chain Management, Vol. 24 No. 4, pp. 469-483.

Csóka, P. and Jean-Jacques Herings, P. (2018), "Decentralized clearing in financial networks", Management Science, Vol. 64 No. 10, pp. 4681-4699.

Dolgui, A., Ivanov, D., Potryasaev, S., Sokolov, B., Ivanova, M. and Werner, F. (2020), "Blockchainoriented dynamic modelling of smart contract design and execution in the supply chain", International Journal of Production Research, Vol. 58 No. 7, pp. 2184-2199.

Flint, D.J. (2004), "Strategic marketing in global supply chains: four challenges", Industrial Marketing Management, Vol. 33 No. 1, pp. 45-50.

Fosso Wamba, S., Kala Kamdjoug, J.R., Epie Bawack, R. and Keogh, J.G. (2020), "Bitcoin, Blockchain and Fintech: a systematic review and case studies in the supply chain", Production Planning and Control, Vol. 31 Nos 2-3, pp. 115-142.

George, R.V., Harsh, H.O., Ray, P. and Babu, A.K. (2019), "Food quality traceability prototype for restaurants using blockchain and food quality data index", Journal of Cleaner Production, Vol. 240, 118021.

Gunasekaran, A., Yusuf, Y.Y., Adeleye, E.O., Papadopoulos, T., Kovvuri, D. and Geyi, D.G. (2019), "Agile manufacturing: an evolutionary review of practices", International Journal of Production Research, Vol. 57 Nos 15-16, pp. 5154-5174.

Hartley, J.L. and Sawaya, W.J. (2019), "Tortoise, not the hare: digital transformation of supply chain business processes", Business Horizons, Vol. 62 No. 6, pp. 707-715.

Hasan, H., AlHadhrami, E., AlDhaheri, A., Salah, K. and Jayaraman, R. (2019), "Smart contract-based approach for efficient shipment management", Computers and Industrial Engineering, Vol. 136, pp. 149-159.

Hastig, G.M. and Sodhi, M.M.S. (2020), "Blockchain for supply chain traceability: business requirements and critical success factors", Production and Operations Management, Vol. 29 No. 4, pp. 935-954, doi: 10.1111/poms.13147.

Helo, P. and Hao, Y. (2019), "Blockchains in operations and supply chains: a model and reference implementation”, Computers and Industrial Engineering, Vol. 136, pp. 242-251.

Holotiuk, F., Pisani, F. and Moormann, J. (2019), "Radicalness of blockchain: an assessment based on its impact on the payments industry", Technology Analysis and Strategic Management, Vol. 31 No. 8, pp. 915-928. 
Hughes, A., Park, A., Kietzmann, J. and Archer-Brown, C. (2019), "Beyond Bitcoin: what blockchain and distributed ledger technologies mean for firms”, Business Horizons, Vol. 62 No. 3, pp. 273-281.

Ivanov, D., Dolgui, A. and Sokolov, B. (2019), "The impact of digital technology and Industry 4.0 on the ripple effect and supply chain risk analytics", International Journal of Production Research, Vol. 57 No. 3, pp. 829-846.

Jensen, T., Hedman, J. and Henningsson, S. (2019), "How TradeLens delivers business value with blockchain technology”, MIS Quarterly Executive, Vol. 18 No. 4, pp. 221-243.

Kamble, S., Gunasekaran, A. and Arha, H. (2019), "Understanding the Blockchain technology adoption in supply chains-Indian context”, International Journal of Production Research, Vol. 57 No. 7, pp. 2009-2033.

Kamble, S.S., Gunasekaran, A. and Gawankar, S.A. (2020), "Achieving sustainable performance in a data-driven agriculture supply chain: a review for research and applications", International Journal of Production Economics, Vol. 219, pp. 179-194.

Kamilaris, A., Fonts, A. and Prenafeta-Boldú, F.X. (2019), "The rise of blockchain technology in agriculture and food supply chains", Trends in Food Science and Technology, Vol. 91, pp. 640-652.

Kittipanya-Ngam, P. and Tan, K.H. (2020), "A framework for food supply chain digitalization: lessons from Thailand”, Production Planning and Control, Vol. 31 Nos 2-3, pp. 158-172.

Kshetri, N. (2018), "1 Blockchain's roles in meeting key supply chain management objectives", International Journal of Information Management, Vol. 39, pp. 80-89.

Kurpjuweit, S., Schmidt, C.G., Klöckner, M. and Wagner, S.M. (2019), "Blockchain in additive manufacturing and its impact on supply chains", Journal of Business Logistics, pp. 1-25, (online version), doi: 10.1111/jbl.12231.

Lezoche, M., Panetto, H., Kacprzyk, J., Hernandez, J.E. and Alemany Díaz, M.M.E. (2020), “Agri-food 4.0: a survey of the supply chains and technologies for the future agriculture", Computers in Industry, Vol. 117, 103187.

Longo, F., Nicoletti, L., Padovano, A., d'Atri, G. and Forte, M. (2019), "Blockchain-enabled supply chain: an experimental study", Computers and Industrial Engineering, Vol. 136, pp. 57-69.

Mandolla, C., Petruzzelli, A.M., Percoco, G. and Urbinati, A. (2019), "Building a digital twin for additive manufacturing through the exploitation of blockchain: a case analysis of the aircraft industry", Computers in Industry, Vol. 109, pp. 134-152.

Manupati, V.K., Schoenherr, T., Ramkumar, M., Wagner, S.M., Pabba, S.K. and Inder Raj Singh, R. (2020), "A blockchain-based approach for a multi-echelon sustainable supply chain", International Journal of Production Research, Vol. 58 No. 7, pp. 2222-2241.

Martinez, V., Zhao, M., Blujdea, C., Han, X., Neely, A. and Albores, P. (2019), "Blockchain-driven customer order management", International Journal of Operations and Production Management, Vol. 39 Nos 6-7-8, pp. 993-1022.

Mattke, J., Hund, A., Maier, C. and Weitzel, T. (2019), "How an enterprise blockchain application in the U.S. Pharmaceuticals supply chain is saving lives", MIS Quarterly Executive, Vol. 18 No. 4, Article 6, pp. 246-261.

Miau, S. and Yang, J.M. (2018), "Bibliometrics-based evaluation of the Blockchain research trend: 2008-March 2017", Technology Analysis and Strategic Management, Vol. 30 No. 9, pp. 1029-1045.

Mickiewicz, T. and Rebmann, A. (2020), "Entrepreneurship as trust", Foundations and Trends in Entrepreneurship, Vol. 16 No. 3, pp. 244-309.

Min, H. (2019), "Blockchain technology for enhancing supply chain resilience", Business Horizons, Vol. 62 No. 1, pp. 35-45. 
JOCM 34,2

Min, S., Zacharia, Z.G. and Smith, C.D. (2019), "Defining supply chain management: in the past, present, and future", Journal of Business Logistics, Vol. 40 No. 1, pp. 44-55.

Montecchi, M., Plangger, K. and Etter, M. (2019), "It's real, trust me! Establishing supply chain provenance using blockchain”, Business Horizons, Vol. 32 No. 3, pp. 283-293.

Nakamoto, S. (2008), Bitcoin: A Peer-to-Peer Electronic Cash System, Satoshi Nakamoto Institute, 2008-10-31, available at: https://bitcoin.org/bitcoin.pdf (accessed 2 January 2021).

Olsen, T.L. and Tomlin, B. (2020), "Industry 4.0: opportunities and challenges for operations management”, Manufacturing and Service Operations Management, Vol. 22 No. 1, pp. 113-122, doi: 10.1287/msom.2019.0796.

Parkin, J. (2019), “The senatorial governance of Bitcoin: making (de)centralized money”, Economy and Society, Vol. 48 No. 4, pp. 463-487.

Pedersen, A.B., Risius, M. and Beck, R. (2019), "A ten-step decision path to determine when to use blockchain technologies”, MIS Quarterly Executive, Vol. 18, pp. 99-115.

Pournader, M., Shi, Y., Seuring, S. and Koh, S.C.L. (2020), "Blockchain applications in supply chains, transport and logistics: a systematic review of the literature", International Journal of Production Research, Vol. 58 No. 7, pp. 2063-2081.

Queiroz, M.M., Telles, R. and Bonilla, S.H. (2019), "Blockchain and supply chain management integration: a systematic review of the literature", Supply Chain Management, Vol. 25 No. 2, pp. 241-254.

Rahmanzadeh, S., Pishvaee, M.S. and Rasouli, M.R. (2020), "Integrated innovative product design and supply chain tactical planning within a blockchain platform", International Journal of Production Research, Vol. 58 No. 7, pp. 2242-2262.

Saberi, S., Kouhizadeh, M., Sarkis, J. and Shen, L. (2019), "Blockchain technology and its relationships to sustainable supply chain management", International Journal of Production Research, Vol. 57 No. 7, pp. 2117-2135.

Schmidt, C.G. and Wagner, S.M. (2019), "Blockchain and supply chain relations: a transaction cost theory perspective", Journal of Purchasing and Supply Management, Vol. 25 No. 4, 100552.

Schmitz, J. and Leoni, G. (2019), "Accounting and auditing at the time of blockchain technology: a research agenda”, Australian Accounting Review, Vol. 29 No. 4, pp. 331-342.

Spadoni, R., Nanetti, M., Bondanese, A. and Rivaroli, S. (2019), "Innovative solutions for the wine sector: the role of startups", Wine Economics and Policy, Vol. 8 No. 2, pp. 165-170.

Swan, M. (2015), Blockchain: Blueprint for a New Economy, O'Reilly Media, Sebastopol, CA.

Tang, C.S. and Veelenturf, L.P. (2019), "The strategic role of logistics in the industry 4.0 era", Transportation Research Part E: Logistics and Transportation Review, Vol. 129, pp. 1-11.

Tranfield, D., Denyer, D. and Smart, P. (2003), “Towards a methodology for developing evidenceinformed management knowledge by means of systematic review", British Journal of Management, Vol. 14, pp. 207-222.

van Hoek, R. (2019), "Unblocking the chain - findings from an executive workshop on blockchain in the supply chain”, Supply Chain Management, Vol. 25 No. 2, pp. 255-261.

van Hoek, R. (2020), "Developing a framework for considering blockchain pilots in the supply chain lessons from early industry adopters", Supply Chain Management, Vol. 25 No. 1, pp. 115-121.

Vergne, J.P. and Swain, G. (2016), "Categorical anarchy in the U.K.? The British media's classification of Bitcoin and the limits of categorization", SSRN Electronic Journal, Vol. 51, pp. 187-222.

Wang, Y., Singgih, M., Wang, J. and Rit, M. (2019), "Making sense of blockchain technology: how will it transform supply chains?", International Journal of Production Economics, Vol. 211, pp. 221-236.

Yadav, S. and Singh, S.P. (2020), "Blockchain critical success factors for sustainable supply chain", Resources, Conservation and Recycling, Vol. 152, 104505. 
Yang, C.S. (2019), "Maritime shipping digitalization: blockchain-based technology applications, future improvements, and intention to use", Transportation Research Part E: Logistics and Transportation Review, Vol. 131, pp. 108-117.

Yin, H.H.S., Langenheldt, K., Harlev, M., Mukkamala, R.R. and Vatrapu, R. (2019), "Regulating cryptocurrencies: a supervised machine learning approach to de-anonymizing the Bitcoin blockchain", Journal of Management Information Systems, Vol. 36 No. 1, pp. 37-73.

Yoon, J., Talluri, S., Yildiz, H. and Sheu, C. (2020), "The value of Blockchain technology implementation in international trades under demand volatility risk", International Journal of Production Research, Vol. 58 No. 7, pp. 2163-2183.

Yu, T., Lin, Z. and Tang, Q. (2018), "Blockchain: the introduction and its application in financial accounting", Journal of Corporate Accounting and Finance, Vol. 29 No. 4, pp. 37-47, doi: 10.1002/ jcaf.22365.

Zhang, A., Zhong, R.Y., Farooque, M., Kang, K. and Venkatesh, V.G. (2020), "Blockchain-based life cycle assessment: an implementation framework and system architecture”, Resources, Conservation and Recycling, Vol. 152, 104512.

Zhao, G., Liu, S., Lopez, C., Lu, H., Elgueta, S., Chen, H. and Boshkoska, B.M. (2019), "Blockchain technology in agri-food value chain management: a synthesis of applications, challenges and future research directions", Computers in Industry, Vol. 109, pp. 83-99.

\section{Corresponding author}

Antonello Cammarano can be contacted at: acammarano@unisa.it 
JOCM

34,2

Journal name

International Journal of Production Research

IEEE Transactions on Systems: Man And Cybernetics

Business Horizons

Applied Energy

International Journal of Information Management

Computers and Industrial Engineering

Technological Forecasting and Social Change

Electronic Markets

IEEE Transactions on Engineering Management

PlosOne

Electronic Commerce Research and Applications

Industrial Management and Data Systems

Global Networks

Supply Chain Management: An International Journal

Economics Letters

Mis Quarterly Executive

Transportation Research Part E

Decision Support Systems

Energies

International Journal of Production Economics

Journal of Cleaner Production

Journal of Cultural Economy

Journal of the Association for Information Systems

Renewable and Sustainable Energy Reviews

Research in International Business and Finance

Resources, Conservation and Recycling

The Review of Financial Studies

Communications of The ACM

Computers in Industry

Federal Reserve Bank of St. Louis REVIEW

IEEE Systems Journal

Information Systems and e-Business Management

Information Systems Frontiers

Journal of Business Logistics

Table A1.

Journal-wise distribution of selected papers
Production Planning and Control

Research Policy

Trends in Food Science and Technology

(Other journals with less of 3 publications of BT)
\# Articles

14

13

11

11

11

10

10

9

9

9

8

7

6

6

5

5

5

4

4

4

4

4

4

4

4

4

4

3

3

3

3

3

3

3

3

3

3

105 